\title{
Emerging Lessons from Half a Century of Fiscal Federalism in Switzerland ${ }^{a}$
}

\author{
Kurt SCHMidheinY ${ }^{\mathrm{b}}$
}

\begin{abstract}
SUMMARY
Over the last six years, researchers collaborating through the SNF Sinergia Project have collected data on fiscal federalism in Switzerland over more than half a century. The analysis of these new data in a range of projects has generated new and robust evidence on fiscal interdependencies among local governments and on behavioral responses of households facing local differences. This article presents some of the data collected and reports on nine examples of associated research projects.
\end{abstract}

a This text is based on the keynote address I gave on June 10, 2016 at the annual congress of the Swiss Society of Economics and Statistics (SSES) in Lugano. A video recording of the keynote lecture is available online at https://youtu.be/XhvmMm8bLCA. I thank Marius Brülhart, Monika Bütler, Patricia Funk, Mario Jametti, Raphaël Parchet, Marcus Roller, Anja Roth and Michaela Slotwinski for their help in preparing both keynote lecture and this text.

b University of Basel, CEPR and CESifo. Address: Wirtschaftswissenschaftliche Fakultät, Peter Merian-Weg 6, 4002 Basel, Switzerland; email: kurt.schmidheiny@unibas.ch. 


\section{Introduction}

Switzerland represents a unique laboratory for the study of decentralized decision making and financing of public goods. The experience of the Swiss Confederation since 1848 can be seen as a real-world large-scale experiment. While the empirical public finance and political economics literatures have exploited Swiss data with considerable success for some time and produced evidence that has proven to be of interest far beyond the national context, the Swiss laboratory in its long-term historical dimension and its small-scale spatial dimension had remained largely unexploited due to a lack of readily available data.

Decentralization of fiscal autonomy to lower levels of government such as cantons and municipalities leads to a variety of governmental institutions and behavioral margins for households and firms. Sub-central levels of government compete with each other and with the central government for the tax base. These interdependent decisions are shaped by local political institutions such as election or budgeting rules and by central political institutions such as fiscal equalization rules and the allocation of responsibilities across levels of government. Households and firms can react to changes in taxation by moving to other local jurisdictions. Understanding the effects of these institutions and the behavioral responses of households and firms is essential for understanding the welfare consequences of fiscal decentralization and ultimately for the design of an optimal institutional framework.

In 2010, a network of Swiss academic economists therefore started to work on a long-term research project funded by the Swiss National Science Foundation (SNSF) with the aim of assembling the most comprehensive longitudinal dataset on fiscal and political decentralization in Switzerland to date that would allow us to learn about the complex interrelation of decentralized institutions with behavioral responses of people and firms. ${ }^{1}$ This article presents some of the data collected over the last six years and reports on nine examples of associated research projects.

1 The Sinergia project "The Swiss Confederation: A Natural Laboratory for Research on Fiscal and Political Decentralization" was funded by the Swiss National Science Foundation (SNSF) from 2010 to 2013 (project 130648) and from 2013 to 2016 (project 147668). SNF regulations stipulate six years as the maximum possible funding period for Sinergia projects. The project's main applicant was Marius Brülhart (Université de Lausanne) with Monika Bütler (Universität St. Gallen), Mario Jametti (Università della Svizzera italiana) and Kurt Schmidheiny (Universität Basel) as co-applicants. In addition to the host universities of the four applicants, researchers from ETH Zürich and Universitat Pompeu Fabra in Barcelona were involved in various sub-projects. A total of 36 senior researchers worked on sub-projects. Formal details 


\section{Fiscal Decentralization in Switzerland}

Switzerland is a federation with one of the highest degrees of tax decentralization to sub-central levels of governments worldwide. In 2014, the 26 cantons and 2,352 municipalities raised $54 \%$ of the country's total tax revenue. ${ }^{2}$ The subcentral tax share was $82 \%$ for personal tax revenue and $52 \%$ for corporate tax revenue. $100 \%$ of wealth tax revenue and $100 \%$ of inheritance taxes are raised sub-centrally. Figure 1 shows the sub-central tax share of Switzerland in comparison to other OECD countries in 2013. ${ }^{3}$ Switzerland ranks second after Canada which is the only country with a similarly high degree of tax decentralization.

Figure 1: Tax decentralization across OECD countries in 2013. Tax revenue on state and local level as a share of general government tax revenue.

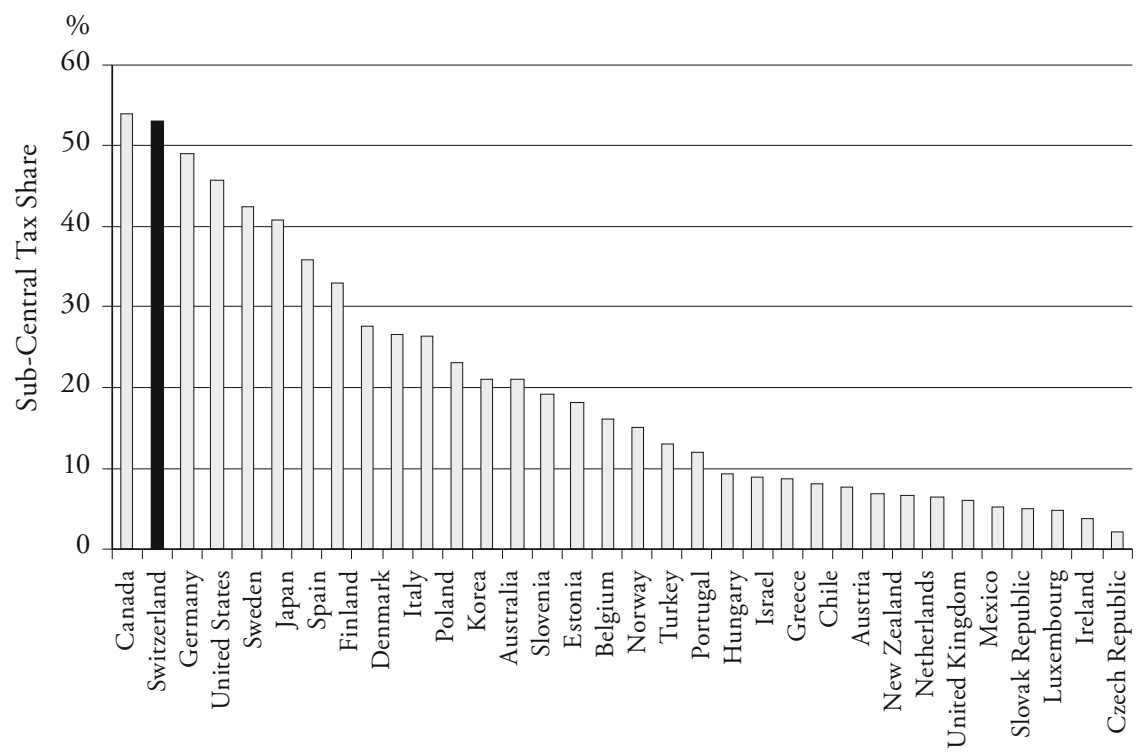

Source: OECD Revenue Statistics.

about the project are available on the SNFS website at http://p3.snf.ch/project-130648 and http://p3.snf.ch/project-147668; details on project collaborators, publications, media contributions, workshops and data can be found on the project website at http://www.fiscalfederalism.ch/.

2 I use the internationally comparable data from the Organisation for Economic Co-operation and Development (OECD) for 2014 available online at http://dx.doi.org/10.1787/data00262-en. Note that OECD data is constantly updated and current numbers can slightly deviate from previously published data. I used data as at June 8, 2016.

3 Data from the OECD for 2013 as at June 7, 2016. 
Figure 2: Jurisdictional fragmentation (average number of municipalities per 100,000 inhabitants, 2012) and local tax decentralization (local tax revenue as a share of general government tax revenue, various years). ALTS considers local tax revenue with real tax autonomy; LTS considers all local tax revenue.

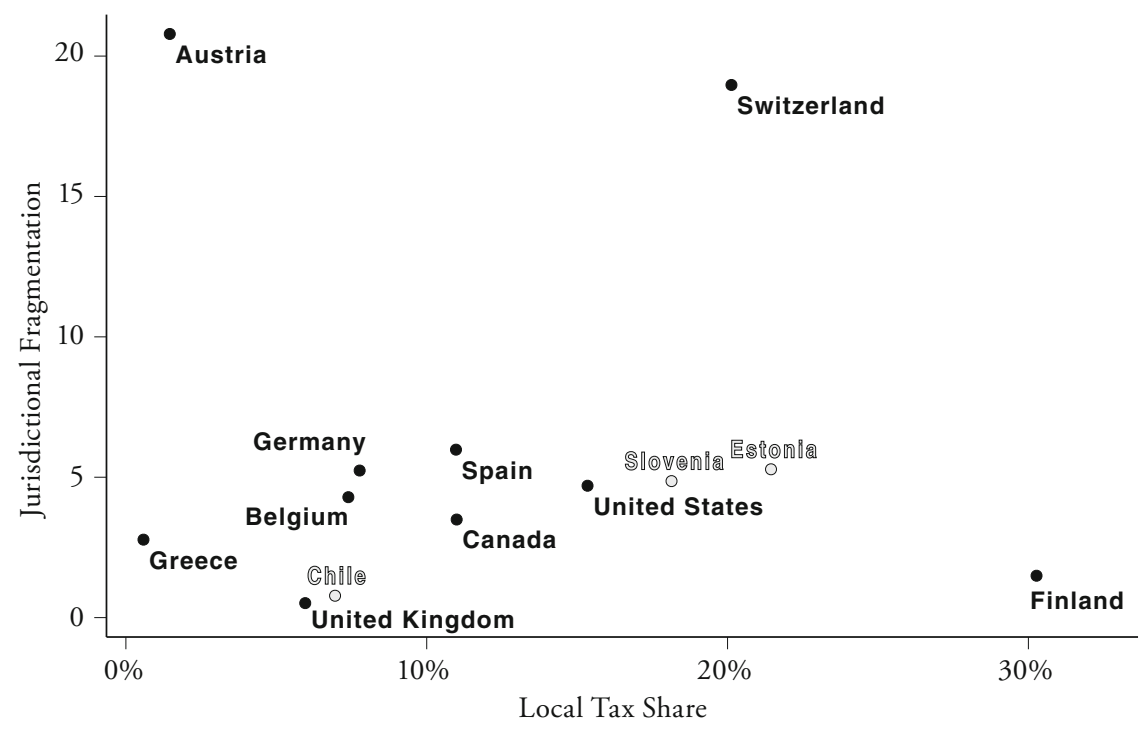

- ALTS (where available) ० LTS (๑therwis@)

Source: Brülhart, Bucovetsky and Schmidheiny (2015).

Switzerland also features a high degree of tax decentralization to the municipal level. In 2014, 20\% of the country's total tax revenue were raised at the municipal level. The municipal tax share was 33\% for household tax revenue and 19\% for corporate taxes. BrülhART, Bucovetsky and SCHMidheiny (2015) document Switzerland's unique degree of municipal tax decentralization in international comparison in the graph reprinted here as Figure 2. First they assess the potential for decentralization at the local, i.e. municipal, level by measuring the number of municipalities per 100,000 inhabitants for OECD countries and selected other countries. By this measure, Switzerland is among the countries with the highest degree of jurisdictional fragmentation. Second, they measure the autonomous local tax share (ALTS), i.e. the share of local tax revenue where the municipalities have real autonomy over determining the tax rate and/or tax base. Switzerland is the only country positioned in the north-east corner, the area with the highest potential for tax competition at the municipal level. While Austria does have a slightly higher degree in jurisdictional fragmentation than Switzerland, Austrian 
"Gemeinden" have no real local taxing power. Finland does have a higher degree of tax decentralization but Finland is fragmented into relatively few "Kommuner". Switzerland is therefore a unique institutional setting to study the effects of fiscal decentralization.

\section{Data Collection}

At the heart of the Sinergia project was the collection of a comprehensive longitudinal database on fiscal and political variables across Swiss cantons and municipalities. The project started by collecting a panel of tax bases and tax rates across all cantons and municipalities since the early 1970s. This dataset is augmented with data on local public finances for a sample of municipalities that grows over time.

\subsection{Cantonal and Municipal Personal and Corporate Income Tax Base}

The Swiss Federal Tax Administration (ESTV) has been storing data on every Swiss taxpayer subject to personal or corporate income tax in electronic format since the fiscal period 1973/74. These data are used to assess the federal tax liability of all households and firms in Switzerland. The ESTV granted researchers from the Sinergia project access to the universe of these records subject to a confidentiality agreement and in exchange to data analysis requested by the federal administration. The individual-level data were made anonymous and could only be accessed by registered and identified researchers in the secured premises of the ESTV in Bern. Sinergia researchers have used this administrative data to generate detailed measures of the tax base at both the municipal and the cantonal level. These descriptive measures generated by the Sinergia project are now publicly available from the Swiss Federal Tax Administration (ESTV). ${ }^{4}$

For the personal income tax base, the publicly available data generated by the Sinergia researchers report detailed descriptive statistics (number, aggregate, mean, median and Gini coefficient) of different measures of the tax base (taxable income, equivalent taxable income corrected for household composition, federal income tax revenue) for all Swiss municipalities and cantons since 1973. In addition, percentiles (e.g. top- $0.01 \%$, top- $0.1 \%$, top- $0.5 \%$, top- $1 \%$,

4 This work was mainly carried out by Raphaël Parchet and Stefanie Brilon at the University of Lausanne under the direction of Marius Brülhart. Data are available online at https://www. estv.admin.ch/estv/de/home/allgemein/steuerstatistiken/fachinformationen/steuerstatistiken/ direkte-bundessteuer.html (Statistische Kennzahlen, Natürliche Personen und Juristische Personen). 
top-2\%, top-decile, top-quartile, median, bottom-quartile, bottom-decile) of taxable income are reported for all cantons since 1973 . For confidentiality reasons, percentiles are not reported for municipalities. ${ }^{5}$ Cantonal numbers are also reported separately for married couples and for single taxpayers.

For the corporate income tax base, the publicly available data generated by the Sinergia project report the number of taxpayers (firms) and the aggregate of different measures of the tax base (profits, equity, federal tax revenue) for all Swiss municipalities and cantons since 1973.

\subsection{Cantonal and Municipal Personal Income Tax Rates}

Measuring the fiscal burden from personal income taxation in a given municipality in Switzerland is a challenging task. Personal income is taxed at the federal, cantonal, and municipal level, with each level applying different tax schedules which may in addition depend on marital status. There are also different deductions for underage children in the household and different subsidies for health insurance to low-income households. The Swiss Federal Tax Administration (ESTV) has been evaluating cantonal and municipal tax laws and calculated the individual combined (cantonal + municipal + church) tax burden for different household types (single taxpayer, married couple with no children, married couple with two children) and selected levels of nominal income since $1949 .{ }^{6}$ The tax burden is expressed in percentage of gross labor income and hence constitutes effective tax rates for the reported income levels taking into account the different tax schedules, deductions and subsidies. The reported income levels are income before social security contributions (AHV, IV, EO, ALV, pension fund), before deductions for children and before tax payments. ${ }^{7}$ Linear interpolation

5 The data at the Federal Tax Administration only recorded taxpayer with a positive tax liability at the federal level before 1995. Incomes at the bottom end of the income distribution are therefore missing between fiscal years 1973/1974 and 1993/1994 even if they are taxed at the cantonal and municipal level. While these missing incomes are very influential for averages and percentiles of the observed taxpayers as reported in the publicly available tables they are negligible when reporting total taxable income in the aggregate or per capita divided by the total population taken from the census.

6 Until 1982 only the tax burden for married couples with no children is reported. The raw data from the ESTV is available online at https://www.estv.admin.ch/estv/de/home/allgemein/ steuerstatistiken/fachinformationen/steuerbelastungen/steuerbelastung.html

7 The reported income levels vary by year. There were e.g. 12 income levels in 1955 (5k, 6k, $8 \mathrm{k}, 10 \mathrm{k}, 12 \mathrm{k}, 15 \mathrm{k}, 20 \mathrm{k}, 25 \mathrm{k}, 30 \mathrm{k}, 40 \mathrm{k}, 50 \mathrm{k}, 100 \mathrm{k})$ and 24 income levels in $2014(12.5 \mathrm{k}, 15 \mathrm{k}$, $17.5 \mathrm{k}, 20 \mathrm{k}, 25 \mathrm{k}, 30 \mathrm{k}, 35 \mathrm{k}, 40 \mathrm{k}, 45 \mathrm{k}, 50 \mathrm{k}, 60 \mathrm{k}, 70 \mathrm{k}, 80 \mathrm{k}, 90 \mathrm{k}, 100 \mathrm{k}, 125 \mathrm{k}, 150 \mathrm{k}, 175 \mathrm{k}, 200 \mathrm{k}$, $250 \mathrm{k}, 300 \mathrm{k}, 400 \mathrm{k}, 500 \mathrm{k}, 1 \mathrm{~m})$. 
between reported income levels and assuming a constant top marginal tax rate makes it possible to infer average tax rates (ATR) quite precisely for all income levels. In particular, it is possible to infer average tax rates for certain percentiles of the income distribution such as for the median taxpayer, the top-10\% or the top- $1 \%$. The data also allow researchers to approximate the marginal tax rates (MTR) although somewhat less accurately.

These data were reported for only 244 larger municipalities (in German called "Indexgemeinden") from 1955 to 1972 and then for an increasing number of municipalities reaching 884 in 2008. Since 2009 individual tax burdens are reported for all the roughly 2,500 Swiss municipalities. The early data until 1995 were published in printed format and later scanned as images, data from 1996 to 1999 were archived in electronic format but not published, data from 2000 to 2004 were published in machine-readable text format, and since 2005 all data are published as electronic spreadsheets.

Sinergia researchers have in a first step rescanned all printed documentation from 1955 to 1995 in high resolution, digitized the numbers with optical character recognition software, checked for internal consistency and imported them into electronic spreadsheets. ${ }^{8}$ Sinergia researchers have in a second step collected municipal tax multipliers (in German "Steuerfüsse") and church tax multipliers from cantonal and municipal archives from 1955 onwards. ${ }^{9}$ RAPHAËL PARCHET (2014) developed an algorithm which allowed to exactly calculate the local tax burden for all Swiss municipalities by combining local tax multipliers with the digitized ESTV publications.

This joint effort now allows researchers to work with a comprehensive panel of effective local income tax rates for Swiss municipalities from 1955 onward. ${ }^{10}$

8 This work was carried out by Kurt Schmidheiny and his team of research assistants (Miguel Santos, Dominique Meissburger, and Jörg Kalbfuss) at Pompeu Fabra University in Barcelona and the University of Basel.

9 This work was carried out by Raphaël Parchet and his team of research assistants (Veronica Grassi, Jessica Villiger, Santhosh Mannamplackal, Manuel Schuler, Elsa Bouzaglo) at the University of Lausanne and the Università della Svizzera italiana.

10 Raphäl Parchet (Università della Svizzera italiana) and his team are currently working on extending this database to all Swiss municipalities from 1949 onward. 
Figure 3: Consolidated cantonal + municipal effective average tax rate across Swiss cantons in 2014 for a married couple with two children and top-1\% income. Average across municipalities weighted by the number of taxpayers.

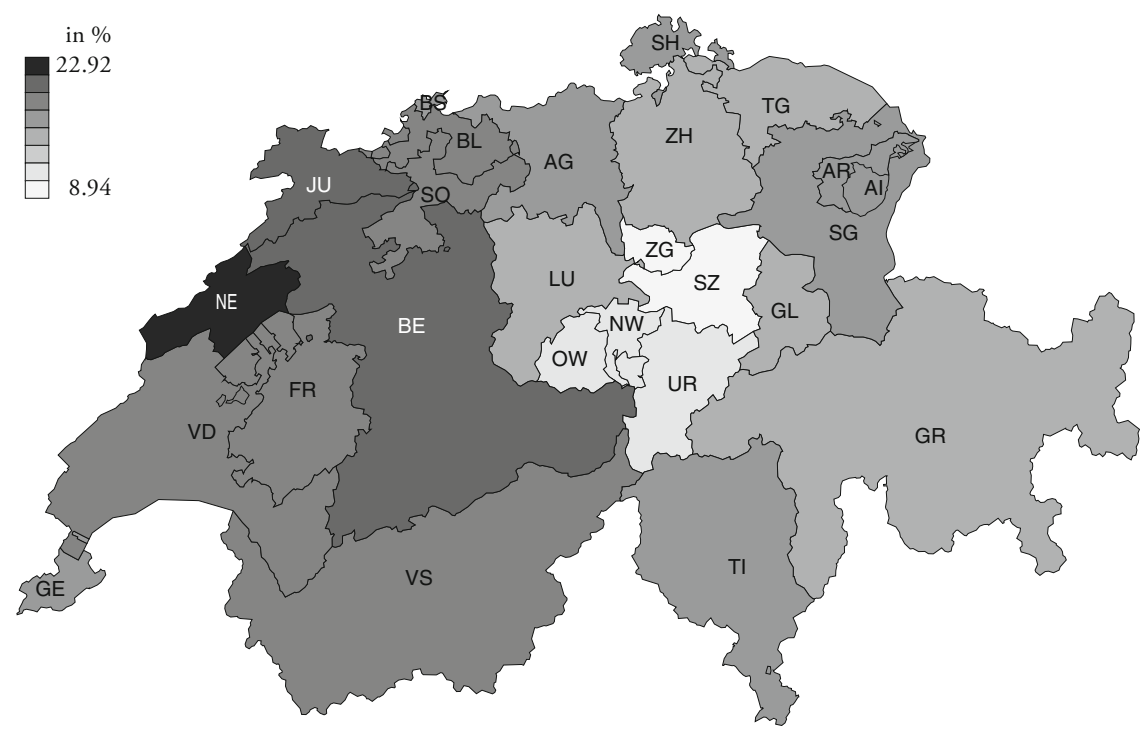

\section{Tax Rates and Tax Bases in Space and Time}

The data collected within the Sinergia project allow us for the first time to precisely study the spatial distribution and temporal evolution of tax rates and tax bases across Swiss cantons and municipalities.

Figure 3 maps the consolidated sub-central tax burden that a married couple with two children and an income at the $99^{\text {th }}$ percentile (top-1\%) of the countrywide income distribution (318,100 Swiss francs) faced across Swiss cantons in $2014 .{ }^{11}$ Note that we do not add the federal income tax burden of $6.13 \%$ in 2014 for this household because it does not vary across Switzerland. The tax burden is

11 The countrywide percentiles, e.g. top-1\%, top-10\%, median, of gross income are estimated from the individual ESTV data. The ESTV data includes a measure of net income called "Reineinkommen". We approximate gross income by multiplying "Reineinkommen" with a factor 1.25 to add social security contributions and other standard deductions. We do use percentiles of the population of all taxpayers including those who paid no federal taxes. The thus created percentiles differ from the percentiles of taxable income produced by the Sinergia project and published on the ESTV website. 
Figure 4: Consolidated cantonal + municipal effective average tax rate across Swiss municipalities in 2014 for a married couple with two children and top-1\% income.

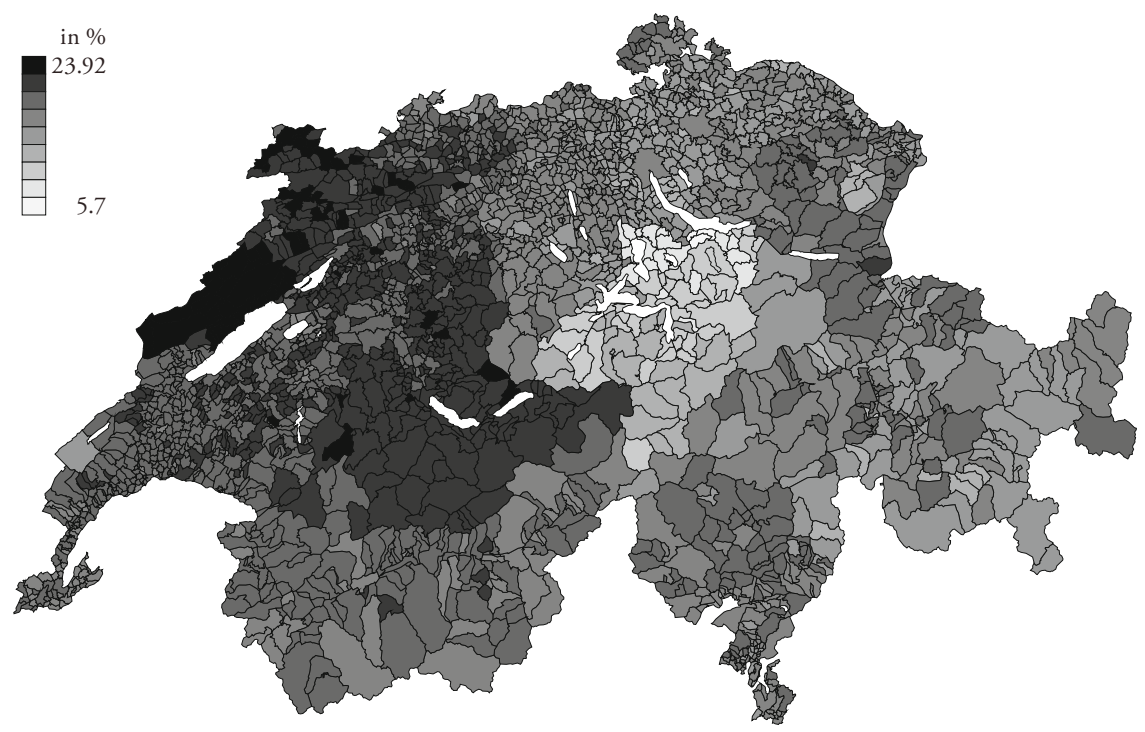

expressed as the effective tax rate, taking into account the different tax schedules and deductions across cantons. Variation across municipalities within cantons is aggregated by averaging the tax burden across all municipalities of a canton weighted by the municipal number of taxpayers in 2014. This weighted average of municipal tax rates is a more representative summary than the often-reported tax burden in the cantonal capital taking into account the potential existence of regional "tax havens". Figure 3 reveals the substantial variation in tax rates ranging from $8.94 \%$ in the canton of $\mathrm{Zug}(\mathrm{ZG})$ to $22.92 \%$ in the canton of Neuchâtel (NE).

We observe even more spatial variation when considering the differences across municipalities within cantons. Figure 4 maps the combined tax burden for the above household across all 2,352 Swiss municipalities in 2014. It ranged from $5.77 \%$ in Wollerau, canton of Schwyz, to $23.92 \%$ in Les Verrières, canton of Neuchâtel. Clearly the larger differences stem from differences in cantonal taxes. However, the variation within cantons is also considerable as exemplified in Figure 5 for Zurich, the most populous canton, where the tax rates range from $12.76 \%$ in Küsnacht to $16.81 \%$ in Sternenberg. 
Figure 5: Consolidated cantonal + municipal effective average tax rate across municipalities in the canton of Zurich in 2014 for a married couple with two children and top- $1 \%$ income.

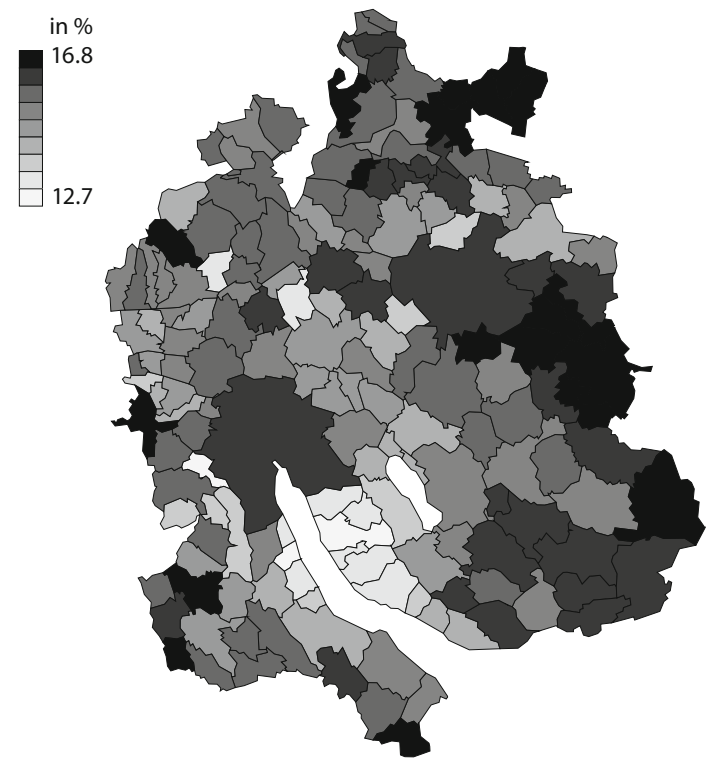

There is also considerable spatial variation in the respective tax base. Figure 6 maps taxable income per year divided by total population across the 26 Swiss cantons in 2012. The canton with the highest tax base in 2012 was Zug (ZG) with taxable income per inhabitant of 57,445 Swiss francs. This is more than twice the fiscal capacity of the canton of Uri (UR) with taxable income of 27,516 Swiss francs per inhabitant.

Variation is even more pronounced when mapping the municipal tax base in Figure 7. The tiny municipality of Lohn in the canton of Graubünden reported taxable incomes of 7,985 Swiss francs per inhabitant in 2012 while the also very small municipality of Vaux-sur-Morges in the canton of Vaud reported taxable incomes of 411,117 Swiss francs per inhabitant. Figure 8 zooms into the canton of Zurich and reveals a spread in taxable income of a factor four, with taxable income per inhabitants of 22,495 Swiss francs in Fischenthal compared to 88,999 Swiss francs in Uitikon. 
Figure 6: Taxable income per inhabitant across Swiss cantons in 2012.

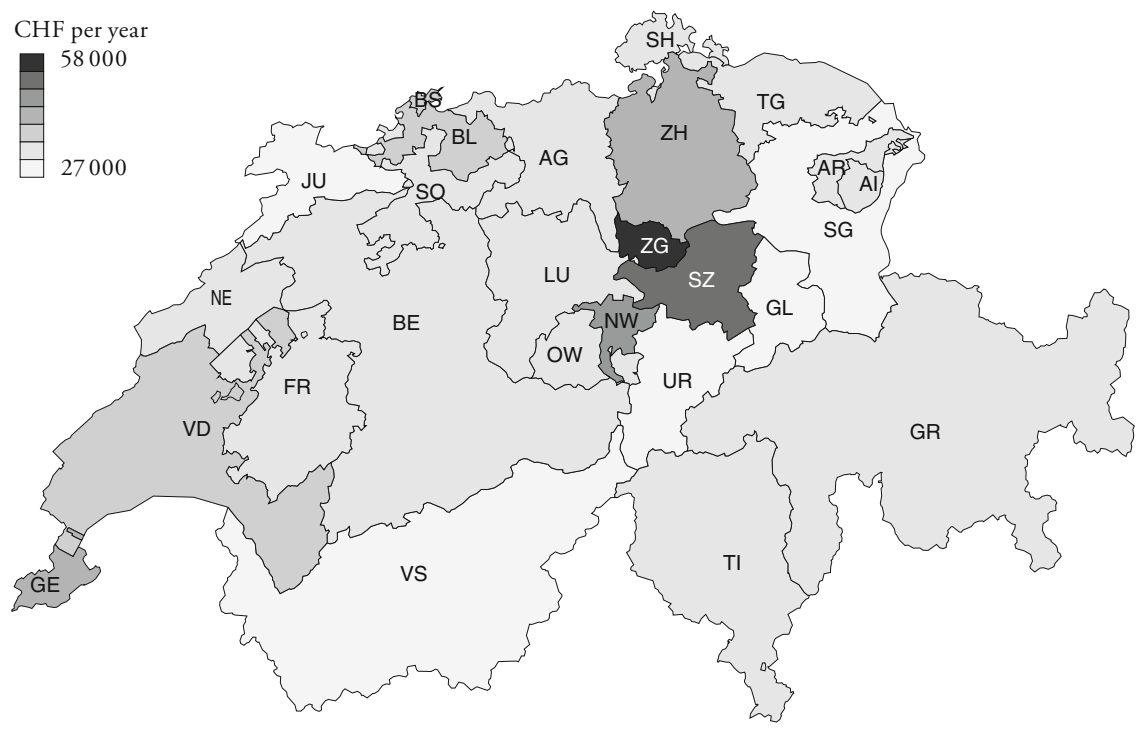

Figure 7: Taxable income per inhabitant across Swiss municipalities in 2012.

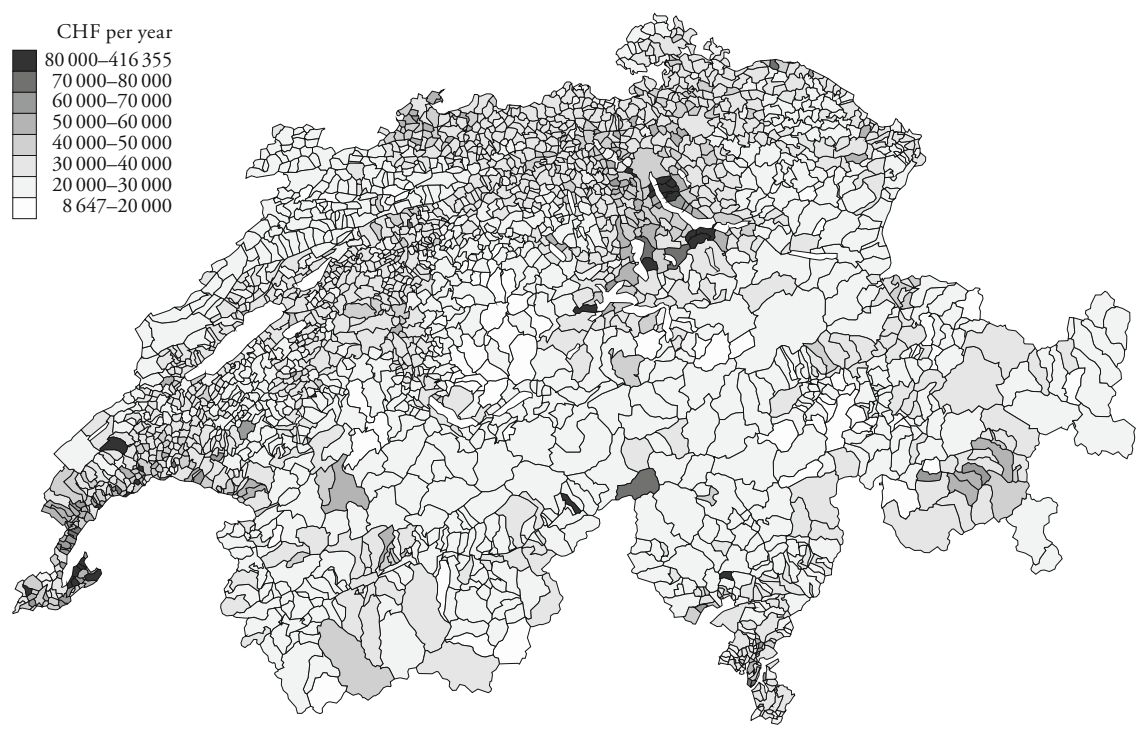


Figure 8: Taxable income per inhabitant across municipalities in the canton of Zurich in 2012.

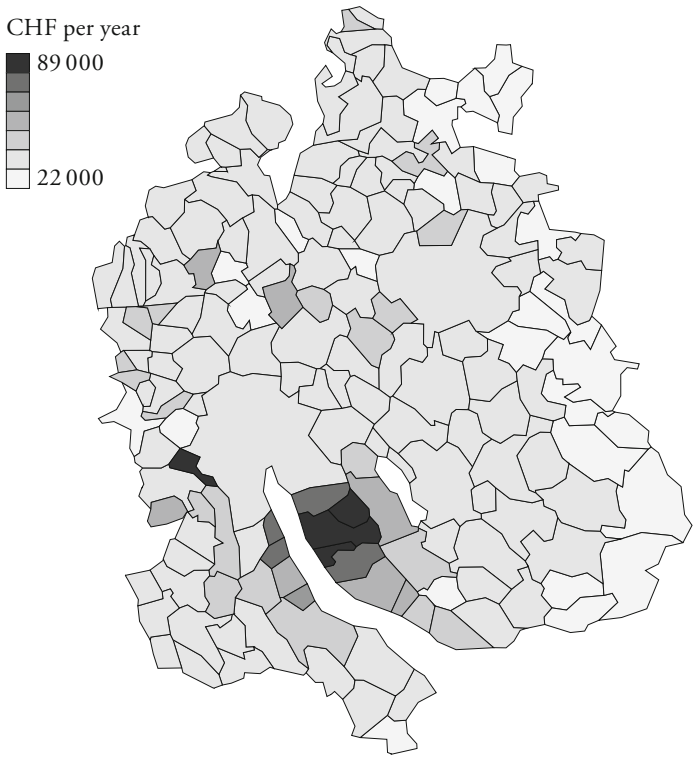

It is of obvious interest to relate local tax base to local rates. Figure 9 is a screenshot from an interactive diagram on the website of the Sinergia project and relates the effective average income tax rate for a married couple without children and gross income at the $90^{\text {th }}$ percentile (top-10\%) of the national income distribution $(120,800$ Swiss francs in 2012) to the taxable income per inhabitants across the 26 Swiss cantons in $2012 .{ }^{12}$ We can observe a clear and statistically significant negative relationship. ${ }^{13}$ While Figure 9 documents a strong negative correlation between tax rate and tax base, it cannot be taken as evidence for a causal relationship as I will discuss in more detail in the Section 6.

12 The interactive diagram is available in a German version online at http://www.fiscalfederalism.ch/data/visual/cantons_np.html. See footnote 11 on our measurement of top-10\% gross income.

13 A bivariate linear regression of income per inhabitants (in logs) on the income tax rate (in percentage points) in 2012 yields a highly significant negative slope coefficient of -0.049 $(p<0.001)$ and a high fraction of explained variance, $\mathrm{R}^{2}=0.43$. 
Figure 9: Taxable income per inhabitant (vertical axis) and Consolidated cantonal + municipal effective average tax rate for a married couple without children and top-10\% income (horizontal axis) across Swiss cantons in 2012. Average across municipalities weighted by the number of taxpayers.

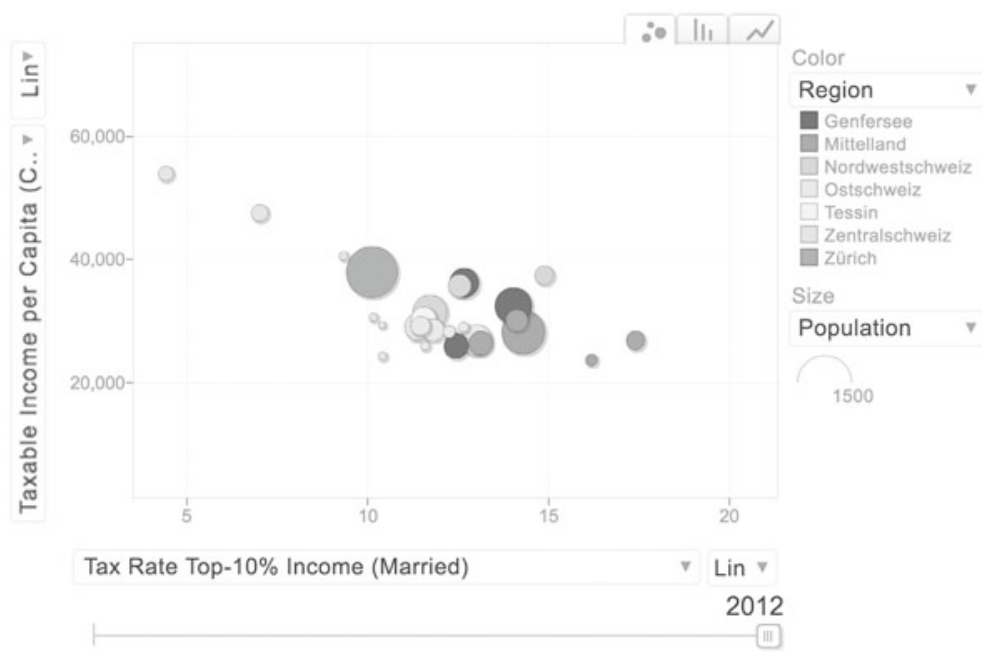

The strong negative relationship between taxable incomes and income tax rates is a relatively recent phenomenon in Switzerland. Figure 10 shows the relation for the year 1972. While there was already considerable variation in tax rates back then, the tax base is relatively equal and not systematically related to tax rates. ${ }^{14}$

Figure 11 trails the completely different evolutionary paths from 1972 to 2012 for the canton of $\mathrm{Zug}(\mathrm{ZG})$ and the canton of Neuchâtel (NE). The two cantons started with similar levels of income tax burden and income tax base in 1972 . While the canton of Zug became the richest canton after a series of tax cuts over the following four decades, the canton of Neuchâtel went through moderate increases and decreases of tax rates ending up among the poorest cantons and with the highest relative tax burden in Switzerland for this household type.

14 A bivariate linear regression of income per inhabitants (in logs) on the income tax rate (in percentage points) in 1972 yields a non-significant slope coefficient of $-0.031(p=0.18)$ and a low fraction of explained variance, $\mathrm{R}^{2}=0.08$. The log transformation of the dependent variable enables a meaningful comparison of the cross-sectional regression results across years because the constant controls for the effect of inflation and growth. 
Figure 10: Taxable income per inhabitant (vertical axis) and Consolidated cantonal + municipal effective tax rate for a married couple without children and top-10\% income (horizontal axis) across Swiss cantons in 1972. Average across municipalities weighted by the number of taxpayers.

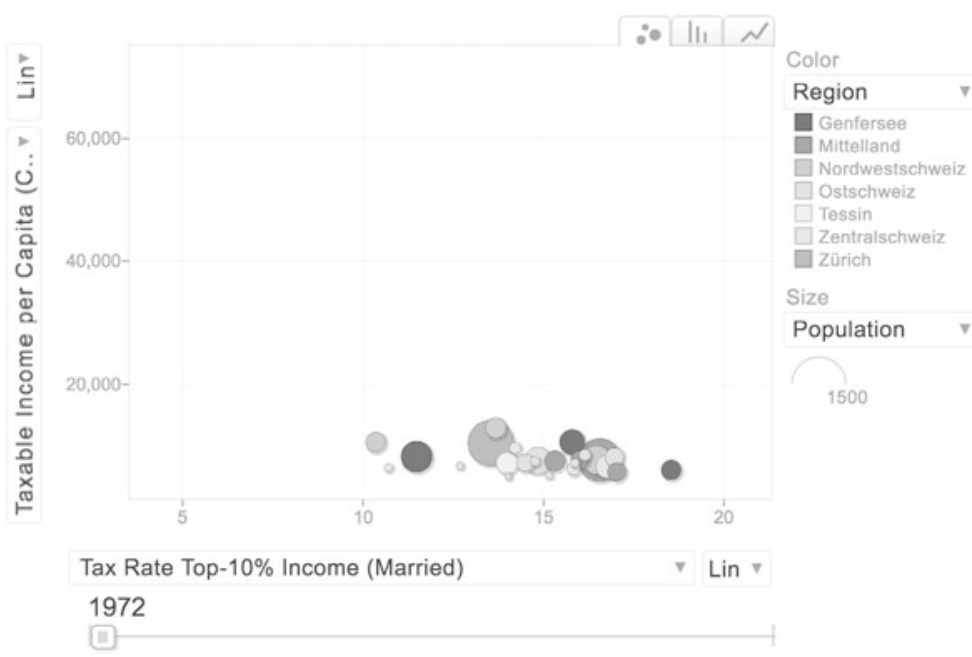

Figure 11: Taxable income per inhabitant (vertical axis) and Consolidated cantonal + municipal effective average tax rate for a married couple without children and top-10\% income (horizontal axis) across Swiss cantons 2012 with evolution since 1972 for the cantons of Zug (ZG) and Neuchâtel (NE). Average across municipalities weighted by the number of taxpayers.

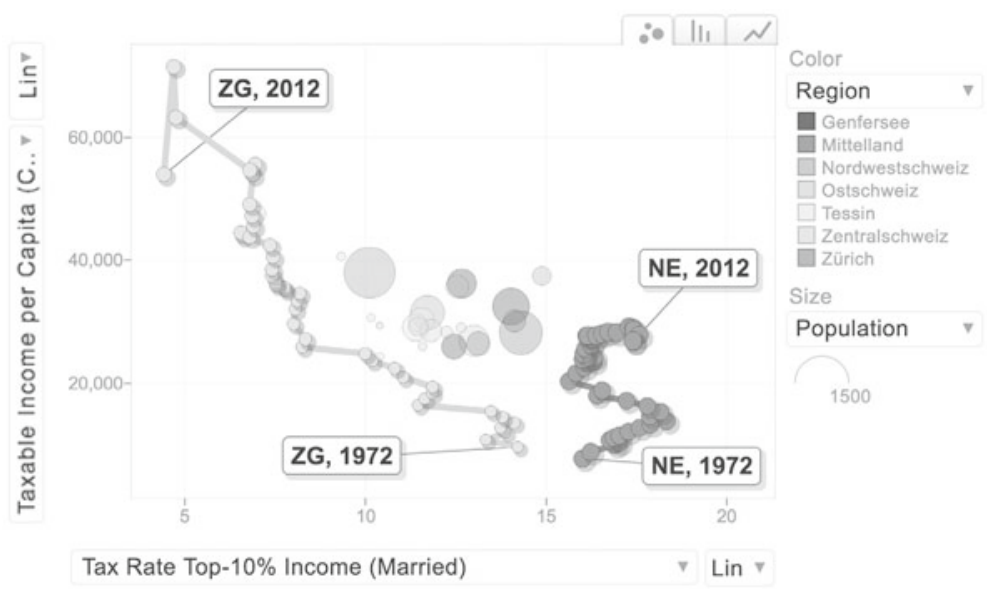


Figure 12: Evolution of consolidated cantonal + municipal effective average tax rate for a married couple without children and top- $10 \%$ income across Swiss cantons from 1970 to 2014. Average across municipalities weighted by the number of taxpayers.

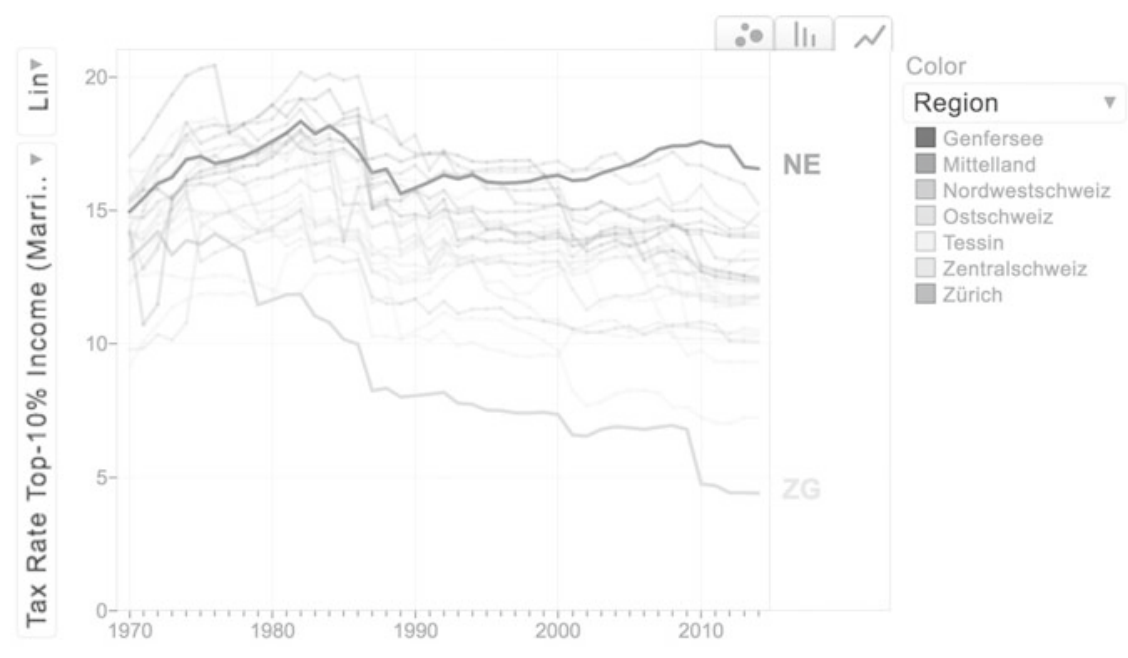

Figure 12 shows another view of the interactive diagram with the time series of the effective average income tax rate for a married couple without children from 1970 to 2014 . In all years, the tax rate is given for a couple with gross income at the $90^{\text {th }}$ percentile (top-10\%) of the national income distribution of the respective year. The $90^{\text {th }}$ percentile of gross income increased from 34,400 Swiss francs in 1970 to 120,500 Swiss francs in 2014. Hence, Figure 12 shows the evolution of the tax burden for a household with the same relative position in the countrywide income distribution over time. This procedure therefore controls both for inflation and for the economic growth that has occurred over the 45 sample years. This is more meaningful than e.g. following the tax burden of nominal incomes. Figure 12 shows a clear trend of falling income tax rates across all cantons since the mid 1980s. This negative trend is particularly remarkable because the progressive Swiss tax schedules mechanically lead to an increase in the tax burden in periods of inflation and economic growth. ${ }^{15}$ The most substantial decrease can be seen for the canton of $\mathrm{Zug}(\mathrm{ZG})$ which reduced its tax rate from a peak of

15 The mechanical increase in the tax burden due to inflation is called "kalte Progression" in German. Many cantonal tax laws and the federal tax law (since 2011) provide rules to adjust the tax schedule for inflation. 
$14.2 \%$ in 1972 by a factor of more than 3 to $4.4 \%$ in 2014 . There are also a few exceptions from this general trend such as the canton of Neuchâtel (NE) which increased its tax rate between 1990 and 2010 back to the level of the mid 1980s. Figure 13 shows the resulting position of the two example cantons in the 2014 ranking of the tax burden for this type of households.

Figure 13: Ranking of consolidated cantonal + municipal effective average tax rate for a married couple without children and top-10\% income across Swiss cantons in 2014.

Average across municipalities weighted by the number of taxpayers.

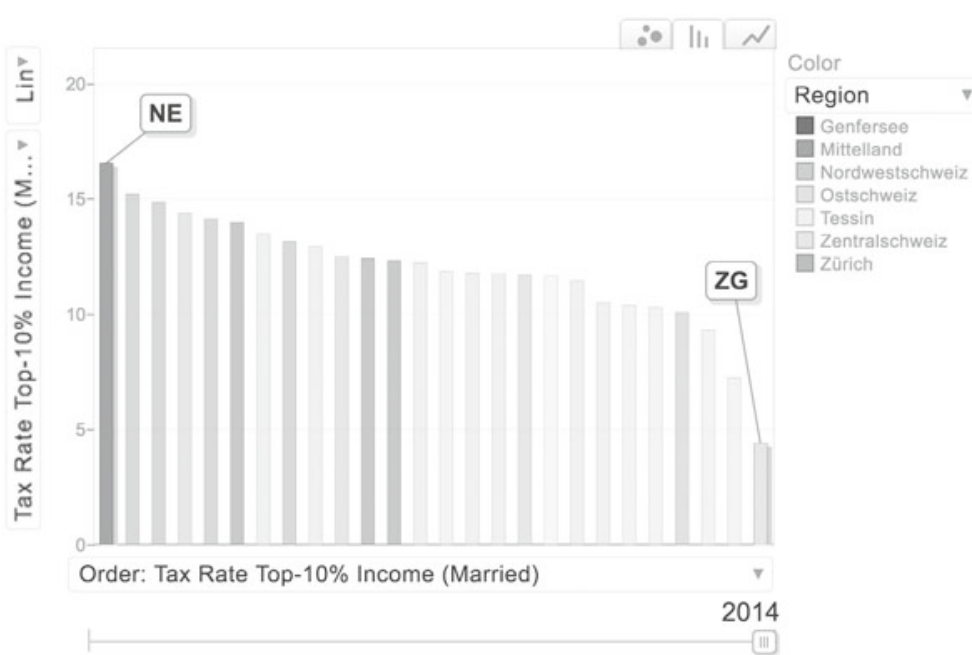

\section{What we Seek to Learn}

The political institutions of fiscal federalism are interrelated with the behavior of households and firms in complex ways. For example, households may react to local income tax rates by adjusting their labor supply and/or by moving to other jurisdictions, while local jurisdictions set their tax base considering the expected local tax base. Potential causal links therefore typically go in both directions, and the econometric identification of their direction and magnitude is challenging. Our Sinergia project aimed at applying various modern tools of econometric identification to the newly collected data. In the following, I will report on nine sub-projects as examples. 


\section{Example No. 1: "Behavioral Responses to Local Tax Rates: Quasi-Experimental Evidence from a Foreigners' Tax Scheme in Switzerland"}

In a fiscally decentralized country, households have the opportunity to move to another jurisdiction when their place of residence changes its tax rates. The local tax base might therefore react more elastically to local tax changes than the national tax base. However, the typically observed negative correlation between local income tax rates and local incomes cannot be taken as evidence for a causal link between tax rates and location choices. The negative relationship could also be reversely caused by local jurisdictions able to lower their tax rates in the wake of increases in taxable incomes that are caused by other factors. KURT SCHMIDHeiny and Michaela Slotwinski (2015) therefore investigate whether there is robust evidence of tax-induced location choices.

This project exploits a special institutional regulation in Swiss tax law that affects foreign nationals during their first years in the country. Foreign nationals whose yearly gross income is below 120,000 Swiss francs are subject to a special tax regime ("Quellenbesteuerung") until they get a permanent residence permit, while foreign nationals with gross income above 120,000 Swiss francs are taxed like Swiss citizens (ordinary taxation). For taxpayers in the ordinary tax regime, income tax rates differ across individual municipalities within cantons, while taxpayers in the special tax regime pay a single rate which is the average of the municipal tax rates within the canton. This results in two types of municipalities: high-tax municipalities where the ordinary tax rate is higher than the special tax rate, and low-tax municipalities where the ordinary tax rate is lower than the special tax rate. Foreign nationals can apply for permanent residency after five years in Switzerland, which shifts them into the ordinary tax regime. This institutional arrangement produces two thresholds which allow identifying the causal effects of local income tax rates using local randomization around them: a duration threshold after 5 years of stay and an income threshold at 120,000 Swiss francs. The duration threshold gives rise to a fuzzy regression discontinuity design (fuzzy RD or FRD) and the income threshold to a sharp regression discontinuity design (sharp RD or SRD).

The empirical application draws on individual data from a large household survey from 2001-2012 merged with individual-level administrative social security information (SESAM) and with the effective tax rates from the Sinergia project described in Section 3.2. The study finds strong mobility effects at the duration threshold: foreign households in the special tax regime who located in a high-tax municipality are likely to move away when they experience a sudden increase in income tax rates after five years of stay in Switzerland. This response 
can be taken as evidence of a causal effect of local tax rates on individuals' location choices; at least for the subgroup of the population subject to the special tax regime. Quite interestingly, the project does not detect such a systematically different behavior at the income threshold during the first five years: foreign households that arrive in Switzerland with income below the income threshold are not systematically more likely to locate in high-tax municipalities than those with incomes above the threshold. However, foreign households that are located in high-tax municipalities systematically seek to keep their income below the income threshold to profit from the lower tax rates in the special tax regime while foreign households in low-tax municipalities seek to keep their income below the threshold. In sum, this evidence suggests that foreign households in Switzerland base their location choices on income tax rates after they personally experience changes on their tax bill.

\section{Example No. 2: "Effective Tax Rates and Effective Progressivity in a Fiscally Decentralized Country"}

In a fiscally decentralized country, mobile taxpayers face a multitude of different local tax schedules. Different types of taxpayers are typically not uniformly distributed across space. High-income households, for example, are more likely to live in low-tax jurisdictions than low-income households. Such spatial income sorting affects the tax rates that taxpayers effectively face on average in Switzerland. Kurt Schmidheiny and Marcus Roller (2016) quantify the effective level and the effective progressivity of income taxation in Switzerland taking income sorting into account.

Schmidheiny and Roller propose to use an average of the tax rates across jurisdictions, weighted by the actually observed spatial location pattern which depends on the taxpayer type. As high-income households are less likely located in high-tax jurisdictions, tax rates of high-tax jurisdictions get less weight when calculating the effective tax rates for high-income households. They call this the relevant effective rate because it is the tax rate that a specific type of taxpayer effectively faces on average in the country. The effective country-wide average tax rate can be consistently estimated by a local polynomial regression using data on the income and location of individual taxpayers. The thus estimated effective country-wide average and marginal tax rates can also be used to calculate standard measures of tax progressivity.

While the logic of this paper is straightforward, the empirical quantification is demanding on data. The project draws on the universe of administrative records of taxpayers in Switzerland over a period of 35 years. These detailed 
data allow for precise quantification of effective tax rates along the whole range of incomes including the top- $1 \%$ and top- $0.1 \%$ taxpayers, arguably the most mobile of taxpayers.

The project finds that rich households effectively face significantly lower average and marginal tax rates and lower progressivity than in the benchmark case that does not consider income sorting. Although income tax schedules of the Swiss federation, the 26 cantons and the more than 2,600 municipalities are all strictly progressive, the effectively paid country-wide average tax rate is even regressive for households with very high incomes and without children. There are heterogeneous results for different household types. For singles, the effective average tax rate is significantly lower than the benchmark from 100,000 Swiss francs onward, starts flattening at around 500,000 Swiss francs and is decreasing after $1 \mathrm{~m}$ Swiss francs. For families with children the difference between the benchmark and the effective average tax rate is smaller.

The proposed measure of the effective average and marginal tax rates also allows us to adequately describe the evolution of the country-wide tax burden over time. It documents that half of the reduction in the tax burden on top incomes between 1975 and 2009 is due to reductions in statutory tax rates and about half to stronger income sorting of the population.

\section{Example No. 3: "The Elasticity of Taxable Wealth: Evidence from Switzerland"}

With inequality having risen in many developed nations over the past four decades, economists increasingly advocate taxation of wealth levels, either annually or at death. Yet, there exists little evidence to date on the behavioral responses triggered by recurrent wealth taxation. Marius BRÜLhart, Jonathan Gruber, Matthias Krapf and Kurt Schmidheiny (2017) therefore seek to estimate the elasticity of taxable wealth from variation in local wealth tax rates across Swiss cantons and municipalities and over time. Switzerland offers a propitious setting for such an empirical study for two reasons: (a) it is the country with the largest level of annual wealth taxation, relative to the size of government, in the developed world, and (b) wealth taxes are raised at the cantonal and municipal level, with no centralized federal wealth taxation.

The effect of wealth tax rates is first explored with respect to reported wealth holdings at the level of Swiss cantons over the decade 2003 to 2012. These panel data permit the use of regressions with fixed effects and cantonal linear time trends controlling for any time-invariant canton-specific factors and for cantonspecific trends. Additionally controlling for income tax rates disentangles the 
effect of wealth and income tax rates on reported wealth holding. It is found that reported wealth holdings in Switzerland are remarkably responsive to wealth taxation: a 0.1 percentage-point rise in wealth taxation lowers reported wealth by 3.5 percent in aggregate. Expressed relative to taxable capital income flows, this implies a net-of-tax elasticity of roughly 0.85 , which is large compared to the elasticities typically estimated in the income literature. The elasticity of tax revenues with respect to tax rates is only -0.18 , however, implying that current rates are well below the revenue maximizing rate.

While the aggregate responses of wealth holdings are the ultimate response of policy interest they do not reveal the underlying mechanisms through which wealth changes. The project therefore also uses administrative individual data of the universe of taxpayers in the canton of Bern from 2001 to 2011 with a total of 6.84 million observations (taxpayer-years). The advantage of these micro data is that wealth is reported in different categories (financial assets, non-financial assets, etc.) and that individuals can be observed longitudinally. This data structure allows separate estimation of the response in wealth holdings of stayers and mobility effects. The response of stayers is estimated in a regression of changes in $\log$ wealth on changes in top wealth tax rates in the taxpayer's residence municipality including municipality and year fixed effects. This design controls for any individual-specific factors, municipality-specific factors and common time trends. Income and wealth tax rates vary across municipalities in the canton based on the same municipal tax multiplier. Effects from changes in wealth tax rates can therefore not be disentangled from changes in income tax rates. The estimates with individual data from the canton of Bern yield a still sizeable response of wealth holdings that is about two-thirds as large as in the aggregate data. Some of this response occurs through bunching below taxable income thresholds and the response is somewhat larger for financial assets than for non-financial assets. However, there is no statistically significant evidence that taxpayers in the canton of Bern relocate due to changes in wealth taxation.

\section{Example No.4: "Alleged Tax Competition:}

The Mysterious Death of Bequest Taxes in Switzerland"

Swiss cantons have all been lowering bequest tax burdens since the late 1980s. Of the 17 cantons that had imposed an inheritance tax on direct descendants and/or spouses in 1973, only three still applied a tax on direct descendants in 2008 , and none taxed inheritances by spouses. The main argument in the political discussion on these tax reforms was typically based on the threat of losing rich taxpayers to cantons with low bequest taxes. But do elderly people really strategically choose 
their place of residence in reaction to differences in the level of bequest taxes? Marius Brülhart and Raphä̈l Parchet (2014) have studied the mobility of elderly taxpayers with Swiss data from 1973 to 2008 and cannot find such link.

Brülhart and Parchet use administrative individual records from the Swiss federal tax administration (ESTV) on all taxpayers from 1973 to 2008. These data allow them to calculate measures of the cantonal tax base for a specific subgroup of the population, namely retired taxpayers. The tax base is alternatively measured as number of taxpayers, pretax personal income, federal tax revenue, and federal tax revenue from the top- $10 \%$ in the income distribution. These tax base measures (in logs) are then regressed on cantonal bequest tax rates, a series of cantonal characteristics which changed over time, linear canton-specific time trends and canton fixed effects in a panel of 26 cantons and 36 years. Canton fixed effects control for any time-invariant cantonal characteristics, and cantonspecific time trends control for exogenous trends in elderly migration. The relevant bequest tax rate is designed as a weighted average - across different bequest size classes and categories of heirs - of effective inheritance tax rates. Weights are defined by the frequency of observed bequests in each class, using administrative individual data for the canton of Vaud, as the necessary details are not contained in the ESTV data.

Brülhart and Parchet do not find a systematic effect of the cantonal bequest tax burden on the tax base from retired taxpayers. The estimated effects are small and not statistically significant at any conventional level of significance. However, they do find a substantial and significant negative effect on the cantonal tax revenue from bequest taxes after a cut in bequest tax rates. The main argument made for lowering bequest taxes in many Swiss cantons therefore appears not to be supported by the data.

\section{Example No. 5: "Are local tax rates strategic complements or strategic substitutes?"}

What is a municipality doing when one of its neighbors is lowering the tax rate? It may lower its tax rate to stay competitive and to not loose mobile tax base. It may also lower its tax rate because it is simply mimicking what it considers best practice. In these two cases of a reaction in the same direction, tax rates are called strategic complements. Alternatively, a municipality may raise it tax rate in response to make up for reduced tax revenue from lost tax base. In this case of a reaction in the opposite direction, tax rates are called strategic substitutes. Welfare implications and policy recommendations are fundamentally different in the two cases. Raphä̈L PARChet (2014) therefore seeks to estimate direction 
and magnitude of tax reaction functions by studying the tax setting behavior of Swiss municipalities between 1983 and 2012.

Tax reaction functions are basically estimated by regressing the tax rates of one municipality on the tax rates of its neighbors either in a cross-section of municipalities or in a panel of municipalities over several years. However, such regressions are problematic for two reasons. First, there is a problem of reverse causality because the tax rates as dependent variable and as explanatory variables are interrelated. Second, there may be many third factors which influence tax rates in a region in the same direction. These factors may be hard to observe and can only partly be controlled for. Raphael Parchet therefore proposed a new empirical strategy to estimate tax reactions functions. The tax burden in Swiss municipalities depends both on the tax rate of the municipality and the tax rate of the canton. If a canton lowers its tax rates this directly affects all municipalities in the same canton. Parchet studies the tax setting behavior of municipalities on both sides of cantonal borders. He uses data from 1983 to 2012 on all Swiss municipalities which are close to a cantonal border. Cantonal borders in mountainous regions are dropped because geographical proximity is misleading there. $\mathrm{He}$ then regresses the tax rate of a municipality on the tax rate of a close neighboring municipality on the other side of the cantonal border including fixed effects for each pair of municipalities. These pair fixed effects control for any observable or unobservable underlying third factor in the border region. In addition, the combined (municipal + cantonal) tax rate of the neighboring municipality is instrumented by the cantonal tax rate. Hence the tax rate of a municipality on one side of the border is related to shocks decided in the remote capital of the canton on the side of the border. This instrumental variable approach deals with the intrinsic reverse causality problem.

Raphael Parchet finds that municipalities typically increase their tax rates when a neighboring municipality lowers its tax rate and vice-versa. Only in the few cases of very large tax changes, do municipalities react by changing their tax rate in the same direction. Local tax rates are therefore mainly strategic substitutes. This result is different from almost all of the previous empirical literature which does not adequately address the problems of reverse causality and of omitted third factors. Swiss municipalities therefore seem not to compete for mobile tax base in normal times but rather aim for a fixed level of expenditure by compensating lost tax base with increased tax rates. 


\section{Example No. 6: "Culture and Taxes: Towards Identifying Tax Competition"}

Beatrix Eugster and RaphaËl Parchet (2013) are working on another attempt to detect the presence of tax competition between municipalities.

The main idea of this project is to exploit a special politico-geographic situation in Switzerland: the country is divided into three main language area (French, German and Italian). In most cases the language frontier is between cantons but there are three cantons (Bern, Fribourg and Valais) in which the German-French language frontier (the "Röstigraben") runs through the canton. Some municipalities within these three cantons have a French speaking majority and some a German speaking one. While municipalities in the same canton share the same institutional and legal framework, there are cultural traits between German and French-speaking areas which are distinctively different. Such differences create exogenous variation in preferences for public expenditure within cantons.

Eugster and Parchet study all municipalities in a narrow band around intracantonal language frontiers. They first establish differences in preferences for public goods expenditures between the two language groups by observing the outcome of 37 federal referenda between 1981 and 2011. These were all referenda which clearly would have led to an increase in expenditures and taxes if adopted. Using a border regression discontinuity design, they show that the French-speaking municipalities close to the language border were more likely to vote "yes" in these referenda by a margin of 9 percentage points. Thus, French-speaking municipalities close to the border have higher preferences for public goods expenditures than German-speaking ones. This difference cannot be explained by major third factors because these municipalities are geographically very close and within the same canton.

In the absence of tax competition, such differences should also be seen in municipal municipal tax rates. In fact, tax rates of French-speaking municipalities far away from the language border are indeed substantially higher than in German-speaking municipalities far away from the language border within the same canton. However, this difference narrows with less distance to the language border and becomes very small and non-significant at the language border. This convergence of tax rates around the language border is consistent with the presence of tax competition but very hard to explain otherwise. The slope of this decline with distance from the language border implies that tax competition exerts its pressure between neighbors up to a distance of $20 \mathrm{~km}$. 


\section{Example No. 7: "Does Tax Competition Tame the Leviathan?"}

Is tax competition good or bad for the well-being of society? The main opposing arguments on this question are straightforward. Advocates of tax harmonization think of politicians as essentially benevolent seekers of the common good, whose ability to offer the desired level of public services is undermined by the disappearance of their tax base and who are forced to shift the tax burden from mobile (rich) to immobile (poor) tax bases. Conversely, those who view tax competition as a force for good consider politicians as self-interested "Leviathans", whose appetite for big government may be held in check by tax competition. Taming of the Leviathan frequently features as a rationale for delegating fiscal powers from national governments to regional authorities - the idea being that sub-national regions will have to compete more fiercely over mobile tax bases than entire countries. MARIUS BRÜLhART and MARIo JAMETTI (2016) are looking for empirical support for either of the two opposing arguments.

Brülhart and Jametti draw on economic theory to empirically distinguish good from bad tax competition. They derive the following theoretical prediction: if, among regions with relatively benevolent governments, smaller regions have higher tax rates, and if, other things are equal, this same relationship is reversed for regions that have relatively less benevolent governments so that smaller regions have lower taxes, then the latter effect can be interpreted as evidence of welfareincreasing "Leviathan-taming".

The theoretical prediction is then taken to data on tax rates across Swiss municipalities from 1990 to 2009. Brülhart and Jametti exploit a useful variation in the Swiss democratic institutions: a sizeable sub-sample of municipalities set tax rates by direct democratic participation of the citizenry via annual town-hall meetings. Executives of these municipalities are arguably more strongly forced to behave "benevolently" than municipal governments without such direct-democratic control over tax setting. Thus, the degree of direct democracy in municipalities' fiscal decision-making systems can be taken as a proxy measure for the benevolence of government.

Brülhart and Jametti regress municipal tax rates on municipal smallness (inverse size) and the interaction of smallness and their proxy for direct democracy in a panel of 362 municipalities observed over 20 years. Municipal fixed effects thereby capture any municipality-specific characteristics not captured by observed time-varying municipality characteristics. They find that, other things equal, less direct-democratic municipalities indeed have higher tax rates. Moreover, they find that, among the "benevolent" municipalities, relatively smaller ones set higher equilibrium tax rates. This relationship is reversed in jurisdictions 
with greater scope for Leviathan government. Hence, the estimation results coincide with the theoretical prediction, and the finding can be interpreted as evidence that tax competition lowers equilibrium taxes because governments are Leviathans. The underlying theory identifies this as evidence of beneficial tax competition.

\section{Example No. 8: "How Taxes Impact the Choice between an Annuity and the Lump Sum at Retirement"}

Behavioral responses to changes in the tax burden often incur high adjustment costs which offset the potential gains. Behavioral responses are therefore best observed when they generate high gains which dominate adjustment costs. Decisions at retirement offer such a situation in Switzerland where the majority of employees is covered by a second pillar pension plan. Monika Bütler and Alma RAMSDEN (2017) track the individual decisions at retirement and link them to the different tax treatment across Swiss cantons and municipalities.

When an employed individual retires in Switzerland, she can withdraw her accumulated second pillar pension wealth either as a lifelong annuity or as a lump sum. While the annuity income is subject to the normal income tax on top of other income, the lump sum is taxed as a one-off capital levy independent of the individual's other income or wealth. In the highly decentralized Swiss tax system, there is not only sizeable variation in tax schedules between cantons and municipalities, but also large differences in the tax treatment of retirement wealth depending on whether it is drawn down as a lump sum or as an annuity. Bütler and Ramsden observe individual annuitization choices using confidential administrative records from a large Swiss insurance company. The dataset includes 14,620 individual cash-out decisions made between the years 2007 and 2015. As all individuals face the same insurance contract and regulation, this setting is an ideal laboratory to analyze how individuals react to differential taxes and take advantage of them to optimize their after-tax wealth or income.

In a first step, the individual's fraction of pension wealth withdrawn as annuity is regressed on the individual's tax rate on the annuity and on the individual's tax rate on the lump sum. The regression results show that taxes are an important determinant of individual annuitization choices: both a higher tax rate on the lump sum and a lower tax rate on the annuity are associated with a significantly higher share of individuals choosing the annuity. Not surprisingly wealthier individuals react more strongly to tax induced variations in annuity pricing. In a second step, Bütler and Ramsden use a regression discontinuity design (RDD) that exploits kinks in the progressive tax schedule for the lump sum for 
identification. The kinks are at threshold values where the marginal tax rate on the lump sum increases. The results provide robust evidence for tax optimization strategies: individuals with wealth just above the threshold are more likely to choose a combination of annuity and lump sum than those with wealth just below the threshold. These tax optimization strategies are implemented only by relatively wealthy individuals for whom such behavior pays off financially.

These findings have important implications for policy. If policy makers try to reduce poverty at advanced ages, taxes might be an alternative or a supplementary measure to mandates and nudges. In particular, a more preferential tax treatment of annuities relative to the one of lump sum payments could induce more individuals to annuitize a share of their pension wealth, thereby reducing the danger that they outlive their assets in old age and need social assistance.

\section{Example No. 9: "How do Electoral Systems Affect Fiscal Policy? Evidence from Cantonal Parliaments, 1890-2000"}

Democratic decisions about public goods may not just reflect the preferences of the electorate but may be shaped by electoral rules, too. Switzerland's fiscal federalism offers the ideal laboratory to empirically study how details of the electoral system influence electoral outcomes because electoral institutions in this small country vary across space and varied over time. Patricia Funk and Christina GathmanN (2013) seized this opportunity to study how the shift from majoritarian to proportional representation in cantonal parliaments shaped the level and composition of public spending.

In the early decades after the foundation of modern Switzerland in 1848, all cantonal parliaments were elected by majoritarian representation. Starting with the canton of Ticino in 1891, 22 out of the then existing 25 cantons adopted proportional representation to date. The last canton to make this transition was the canton of Uri in 1992; the cantons of Appenzell Innerrhoden, Appenzell Ausserrhoden and Graubünden still elect their parliaments by majoritarian representation. ${ }^{16}$ Funk and Gathmann went to the cantonal archives to collect comprehensive data on cantonal public expenditures and revenues dating back to 1890 .

They regress total cantonal public expenditures per capita (in logs) on a dummy variable for proportional representation in a panel of 25 cantons over 111 years from 1890 to 2000. Canton fixed effect thereby control for any time-invariant cantonal characteristics such as the local language while year fixed effects and canton-specific time trends capture the countrywide economic development and

16 The canton of Jura was only founded in 1979 and is therefore not included in the analysis. 
differential long-term cantonal progress. Time-varying factors such as infant mortality or the introduction of woman's suffrage are explicitly controlled for. This fixed effects method basically compares the level of public expenditures before and after the introduction of proportional representation. They find only a modest and statistically not significant positive effect of proportional representation both on total cantonal expenditures and on total cantonal revenue. Proportional representation hence does not seem to increase the overall size of the government.

Funk and Gathmann also dig deeper by regressing individual expenditure categories such as education, welfare, roads and agriculture on the indicator for proportional representation. They find strong positive effects on public spending for education (plus 21\%) and welfare (plus 42\%) while they find a negative effect on roads (minus 29\%) and a weakly negative effect on agriculture. This result supports the theoretical prediction that proportional representation favors public spending with a broad constituency while majoritarian representation favors public spending which is geographically targeted.

\section{Concluding Remarks}

Institutional diversity is arguably a key factor for the success of modern Switzerland since 1848. It creates competition among autonomous local jurisdictions promoting the efficient provision of public goods, it enables local experimentation leading to creative innovation of new and better institutions, and it empowers citizens in local policy making, thus promoting identification with local communities and institutions. However, federalism is currently challenged by major global trends: people, goods, capital and technology are increasingly mobile; inequality is on the rise between and within countries; politics is drifting towards both supranationalism and localism.

Over the last six years, researchers collaborating through the SNF Sinergia Project have collected data on fiscal federalism in Switzerland over more than half a century. The analysis of these new data in a range of projects has generated new and robust evidence on fiscal interdependencies among local governments and on behavioral responses of households facing local differences. ${ }^{17}$ Research by members of the Sinergia project was also directly policy relevant in Switzerland,

17 The list of publications is available online at http://www.fiscalfederalism.ch/publications/. A list of media contributions and media reports is available online at http://www.fiscalfederalism.ch/media/. 
for example, in the government's report on the Swiss national tax equalization scheme (NFA) in $2014 .^{18}$

We have just begun to explore the rich data collected, and much more data remains to be gathered and transformed into exploitable digital formats. There are many fiscal and political institutions such as fiscal equalization rules or municipal mergers which deserve more research. We are also searching for more potential quasi-experimental shifts in our data that can be used to generate robust evidence of causal relationships. Moreover, we are working on extending the data further back in time, as our data, for example, do not yet cover the years which where pivotal for the emergence of most today's "tax havens" after World War II. We would also like to extend the data in scope to study, for example, the competition for firms. Such an undertaking will require intense collaboration with researchers in neighboring disciplines, in order to understand, for example, legal details and accounting rules. We also see a need for more relevant applied theory to develop meaningful estimators and to quantify welfare effects.

Most of the core data collected in the Sinergia project resulted from access to administrative individual data from the federal tax administration. The Sinergia project helped develop the legal and physical framework for academic access to such highly confidential data and could serve as a model for accessing more administrative big data.

\section{References}

Brülhart, Marius, Sam Bucovetsky, and Kurt Schmidheiny (2015), “Taxes in Cities." In: G. Duranton, J.V. Henderson and W. Strange, Handbook of Regional and Urban Economics, Vol. 5B, pp. 1123-1196.

Brülhart, Marius, Jonathan Gruber, Matthias Krapf, and Kurt SchmidHEINy (2017), “The Elasticity of Taxable Wealth: Evidence from Switzerland”, Mimeo, University of Basel and University of Lausanne.

Brülhart, Marius, and Mario Jametti (2016), "Does Tax Competition Tame the Leviathan?" Mimeo, University of Lausanne.

18 Marius Brülhart and Kurt Schmidheiny (2013), "Studie zum Zweiten Wirksamkeitsbericht NFA". Reported in: Der Bundesrat (2014), "Wirksamkeitsbericht 2012-2015 des Finanzausgleichs zwischen Bund und Kantonen”, sections 5.4.2 and 5.4.3. Available online at https://www.admin.ch/ch/d/gg/pc/documents/2479/WiBe_Finanzausgleich_de.pdf. 
Brülhart, Marius, and RaphaËl Parchet (2014), "Alleged Tax Competition: The Mysterious Death of Bequest Taxes in Switzerland", Journal of Public Economics, 111, pp. 63-78.

Bütler, Monika, and Alma Ramsden (2017), "How Taxes Impact the Choice between an Annuity and the Lump Sum at Retirement", University of St. Gallen Discussion Paper, 2017-01.

Eugster, Beatrix, and Raphaël Parchet (2013). "Culture and Taxes. Towards Identifying Tax Competition", University of St. Gallen Discussion Paper 2013-39.

Funk, Patricia, and Christina Gathmann (2013), "How do Electoral Systems Affect Fiscal Policy? Evidence from Canton Parliaments, 1890-2000", Journal of the European Economic Association, 11(5), pp. 1178-1203.

ParChet, RaphaËL (2014), "Are local tax rates strategic complements or strategic substitutes?” IdEP Economic Papers 2014/07.

Roller, Marcus, and Kurt Schmidheiny (2016), "Effective Tax Rates and Effective Progressivity in a Fiscally Decentralized Country", CEPR Discussion Paper 11152.

Schmidheiny, Kurt, and Michaela Slotwinski (2015), "Behavioral Responses to Local Tax Rates: Quasi-Experimental Evidence from a Foreigners' Tax Scheme in Switzerland", CEPR Discussion Paper 10833. 